\title{
REDUCING EROSION IN SORGHUM CROPS WITH MULCHING ${ }^{1}$
}

\author{
THAIS EMANUELLE MONTEIRO DOS SANTOS SOUZA ${ }^{2 *}$, ELISÂNGELA PEREIRA GONÇALVES ${ }^{3}$, \\ DJALMA SILVA PEREIRA ${ }^{4}$, LUANA MENEZES DOS SANTOS ${ }^{3}$, LÍVIA SANTOS MACHADO ${ }^{3}$, \\ EDIVAN RODRIGUES DE SOUZA
}

\begin{abstract}
Researches evaluating the use of mulch has contributing to optimize soil management towards sustainability, and improving soil quality. The objective of this study was to evaluate the efficiency of mulching on the reduction of erosion in a soil with sorghum (Sorghum bicolor L. Moench) crops subjected to simulated rainfall and increased soil organic carbon. The experiment was carried out from August to December 2013 under field conditions, using a randomized block design with three replications. The treatments consisted of sorghum with mulch, using the local vegetation available in the area; and sorghum without mulch. Simulated rainfalls were performed in three different periods of the crop cycle (initial, intermediate, and final), using a rainfall simulator. The use of mulch in soils with sorghum crops was efficient in improving soil water retention in all phases of the crop, and maintaining soil moisture during the rainfall intervals used, resulting in the absence of plant water loss, and greater contribution to soil organic carbon.
\end{abstract}

Keywords: Simulated rainfall. Conservationist management. Organic carbon.

\section{REDUÇ̃̃O DA EROSÃO EM CULTIVO DE SORGO COM COBERTURA MORTA}

\begin{abstract}
RESUMO - Pesquisas que avaliem o uso de cobertura morta no solo tem grande aceitação, uma vez que otimiza o manejo sustentável e melhora a qualidade do solo. Objetivou-se, com o presente trabalho, avaliar a eficiência da cobertura morta na redução das taxas erosivas do solo em cultivo de sorgo (Sorghum bicolor L. Moench) submetido à chuva simulada, bem como o incremento de carbono orgânico no solo. O experimento foi desenvolvido no período de agosto a dezembro de 2013 sob condição de campo, onde foram estabelecidos os seguintes tratamentos: sorgo com cobertura morta $(\mathrm{CM})$ utilizando-se a vegetação espontânea da área e sorgo sem cobertura morta (SM), com três repetições em blocos casualizados. Foi realizada chuva simulada em três períodos distintos (nicial, intermediário e final do ciclo da cultura), utilizando-se um simulador de chuvas. Em todas as fases da cultura, o uso da cobertura morta no solo em cultivo de sorgo se mostrou eficiente por proporcionar maior retenção da umidade no solo, a qual se manteve por mais tempo entre os intervalos de chuva, resultando na ausência de perda de água, além de proporcionar maior aporte de carbono orgânico no solo.
\end{abstract}

Palavras-chave: Chuva simulada. Manejo conservacionista. Carbono orgânico.

\footnotetext{
${ }^{*}$ Corresponding author

${ }^{1}$ Received for publication in $08 / 30 / 2016$; accepted in $02 / 23 / 2017$.

${ }^{2}$ Department of Biophysics and Radiobiology, Universidade Federal de Pernambuco, Recife, PE, Brazil; thaisemanuelle@hotmail.com ORCID: 0000-0003-4768-5839.

${ }^{3}$ Center for Agrarian, Environmental and Biological Sciences, Universidade Federal do Recôncavo da Bahia, Cruz das Almas, BA, Brazil; eligoncalvespereira@hotmail.com - ORCID: 0000-0002-3346-056X, luanamenezes629@hotmail.com - ORCID: 0000-0003-0563-1875, liviamachado88@hotmail.com-ORCID: 0000-0001-6032-0776.

${ }^{4}$ Department of Soil, Universidade Federal de Viçosa, Viçosa, MG, Brazil; djalma.pereira7@gmail.com - ORCID: 0000-0002-3977-7832.

${ }_{5}^{5}$ Department of Agronomy, Universidade Federal Rural de Pernambuco, Recife, PE, Brazil; edivanrs@hotmail.com - ORCID: 0000-00022442-7266.
} 


\section{INTRODUCTION}

Sorghum (Sorghum bicolor L. Moench) is indigenous to Africa and was introduced to Brazil in the early twentieth century. This crop occupies an area of approximately 1.5 million hectares in Brazil, mainly in its arid and semi-arid regions. Sorghum is a species with well adaptation to places with water deficit and high temperatures, and thus, it can be produced under extreme stress conditions. However, a high-water availability in the soil tends to increase sorghum crop yield (ALVINO et al., 2012).

Soil water deficit can cause a significant reduction in the production of agricultural crops. The use of crop residues on the soil surface has been a simple and efficient technique to maintain moisture, reduce temperature and prevent erosion of soils, and supply some nutrients. Mulching is a technique that consists of covering the soil surface with organic (straw, dry leaves, sawdust) or inorganic (stones, gravel, and plastics) materials (SANTOS et al., 2011).

Generally, the materials used for mulching are those found in the property, for example, residues from crops or weeds. This technique protects the soil from the direct impact of rainfall, surface runoff, and erosive processes; it is a surface sealing that reduces temperature and water loss through evaporation, and can supply organic matter to the soil. (CARDOSO et al., 2013). Resende et al. (2005) used wood sawdust, rice husks, wood shavings, and Tifton (Cynodon spp.) grass to evaluate the effect of soil cover on moisture in carrot (Daucus carota L.) crops. Souza et al. (2011) used shredded stem and leaves of common bean as mulch for carrot crops.

Soil covering with crop residues is important, since it increases the rainwater infiltration and is a physical barrier to reduce runoff, preventing the carrying of disaggregated soil particles. The use of rainfall simulator to evaluate soil and water losses can improve the obtaining of important data to evaluate the soil viability and management practices, while considering the soil and water conservation (FERREIRA et al. 2010).

Thus, the objective of this study was to evaluate the efficiency of mulching on the reduction of erosion in a soil with sorghum (Sorghum bicolor L. Moench) crops subjected to simulated rainfall and increased soil organic carbon.

\section{MATERIAL AND METHODS}

The experiment was conducted under field condition, in the Federal University of Recôncavo da Bahia (UFRB), Cruz das Almas BA, Brazil $\left(12^{\circ} 40^{\prime} 9^{\prime \prime} \mathrm{S}\right.$ and $30^{\circ} 60^{\prime} 22^{\prime \prime} \mathrm{W}$, and altitude of $\left.220 \mathrm{~m}\right)$. The region climate is Aw to Am, tropical hot and humid, according to the classification of Köppen. It has average annual rainfall of 1,206 $\mathrm{mm}(1,000$ to $1,300 \mathrm{~mm}$ year $\left.^{-1}\right)$, and average annual temperature of $24.2^{\circ} \mathrm{C}$, with January and February as the hottest months (PEREIRA; ALBANEZ; NAMÉDIO, 2012).

The treatments used were sorghum with mulch, and sorghum without mulch, distributed in a randomized block design with three replications. Sorghum was planted in August 2013 in six plots of $1 \times 3 \mathrm{~m}$, with the larger length in the slope direction. The plots were divided with $20-\mathrm{cm}$ high metal plates with approximately $10 \mathrm{~cm}$ inserted into the soil. Sorghum seeds were planted with spacing of $0.90 \mathrm{~m}$ between rows and $0.50 \mathrm{~m}$ between plants, totaling 10 plants per plot. Three seeds were planted per pit and only one was left after thinning. The treatment with mulch received $1.66 \mathrm{~kg} \mathrm{~m}^{-2}\left(16.6 \mathrm{Mg} \mathrm{ha}^{-1}\right)$ of dry plant cover from residues of weeds that were on the soil before planting the sorghum. The soil of the experimental area was classified according to Embrapa (2006) as cohesive alic Yellow Latosol of sandy clay loam texture (RESENDE et al., 2005).

The soil physical-chemical characterization (Table 1) was performed by Lima (2013) in disturbed and undisturbed soil samples collected from the 0-20 and 20-40 cm layers. The soil physical attributes determined were texture (pipette method), soil density (volumetric ring method), particle density (volumetric balloon method), clay dispersed in water (densimeter method), flocculation degree, moisture at the field capacity, moisture at permanent wilting point, macroporosity, microporosity (tension table method), soil total porosity, hydraulic conductivity, and percentage of aggregates (vertical oscillator). The soil chemical attributes determined were those used in soil fertility evaluation-exchangeable cations, phosphorus, nitrogen, and organic matter. This analysis was performed in the Laboratories of Physics and Chemistry of the UFRB, according to the methodology described by Embrapa (2006).

Soil moisture was evaluated by the standard method in greenhouse in three different periods: sorghum initial stage (12 days after planting), intermediate stage (54 days after planting) and at the end of the cycle (110 days after planting). The soil used for moisture evaluation was sampled using a Dutch auger, at depth of $10 \mathrm{~cm}$ before and after a 30-min simulated rainfall.

The rainfall was simulated with $80-100$ Vejet spraying nozzles attached to a spraying system. Fourteen pluviometers made of PVC pipes $-10 \mathrm{~cm}$ in diameter and $21 \mathrm{~cm}$ in height-were distributed around the experimental plots. The time interval between the beginning of the rain and beginning of the flow for each treatment was measured. 
T. E. M. S. SOUZA et al.

Table 1. Physical and chemical characteristics of the cohesive alic Yellow Latosol of the experimental area in the layers $0-20$ and $20-40 \mathrm{~cm}$.

\begin{tabular}{|c|c|c|c|c|c|c|c|c|c|c|c|c|c|}
\hline Layer & Sand & Silt & Clay & $\mathrm{CDW}$ & FD & Mac. & Mic. & STP & $\theta_{\mathrm{fc}}$ & pwp & $\mathrm{SD}$ & $\mathrm{PD}$ & $\mathrm{K}_{0}$ \\
\hline & & $\mathrm{g} \mathrm{kg}^{-1}$ & & \multicolumn{2}{|c|}{$\%$} & \multicolumn{3}{|c|}{$\mathrm{m}^{3} \mathrm{~m}^{-3}$} & $\mathrm{~cm}^{3}$ & & \multicolumn{2}{|c|}{$\mathrm{g} \mathrm{cm}^{3}$} & $\mathrm{~cm} \mathrm{~h}^{-1}$ \\
\hline $0-20 \mathrm{~cm}$ & 535 & 245 & 220 & 7.16 & 67.45 & 0.17 & 0.21 & 0.38 & 0.18 & 0.1 & 1.46 & 2.38 & 0.16 \\
\hline $20-40 \mathrm{~cm}$ & 700 & 52 & 248 & 7.16 & 71.13 & 0.2 & 0.21 & 0.41 & 0.17 & 0.16 & 1.49 & 2.53 & 5.49 \\
\hline \multirow[t]{2}{*}{ Layer } & \multirow{2}{*}{\multicolumn{2}{|c|}{$\begin{array}{c}\mathrm{pH} \\
\mathrm{H}_{2} \mathrm{O}\end{array}$}} & $\mathrm{Ca}$ & $\mathrm{Mg}$ & $\mathrm{K}$ & $\mathrm{Na}$ & $\mathrm{Al}$ & $\mathrm{H}+\mathrm{Al}$ & $\mathrm{P}$ & $\mathrm{N}$ & $\mathrm{OM}$ & & $\mathrm{C}$ \\
\hline & & & \multicolumn{6}{|c|}{ cmolc kg $^{-1}$} & $\mathrm{mg} \mathrm{dm}$ & & \multicolumn{3}{|c|}{$\mathrm{g} \mathrm{kg}^{-1}$} \\
\hline $0-20 \mathrm{~cm}$ & \multicolumn{2}{|c|}{5.1} & 0.3 & 0.1 & 1.35 & 9.08 & 0.9 & 2.9 & 2.16 & 5.56 & 7.24 & & 4.2 \\
\hline $20-40 \mathrm{~cm}$ & \multicolumn{2}{|c|}{4.9} & 0.2 & 0.2 & 0.92 & 3.55 & 0.9 & 3.3 & 1.35 & 5.33 & 7.15 & & 4.15 \\
\hline
\end{tabular}

$\mathrm{CDW}=$ clay dispersed in water, $\mathrm{FD}=$ flocculation degree, $\mathrm{Mac} .=$ macroporosity, $\mathrm{Mic}=$ microporosity, $\mathrm{STP}=$ soil total porosity, $\mathrm{q}_{\mathrm{fc}}=$ moisture at field capacity, $\mathrm{q}_{\mathrm{pwp}}=$ moisture at permanent wilting point, $\mathrm{SD}=$ soil density, $\mathrm{PD}=$ particle density, $\mathrm{K}_{0}=$ hydraulic conductivity. Source: Lima (2013).

The first waters were collected from the beginning of the runoff in the collecting channels of the experimental plots, and the subsequent ones in regular intervals of 5 minutes, with duration of 10 seconds. This material was stored in plastic pots and taken to the laboratory to evaluate the erosive rates.

The precipitation intensity was evaluated with a simulator set with a worked pressure of $50 \mathrm{kPa}$ and duration of 30 minutes. The precipitation had a mean constant intensity of $86.77 \mathrm{~mm} \mathrm{~h}^{-1}$. The water loss was calculated based on the volume collected from the runoff per area of the plots.

Soil loss rates and sediment concentration were estimated by weighing the collected material. After weighing, the pots stood for 24 hours, the supernatant was removed, and the pots were taken to a drying oven at $65^{\circ} \mathrm{C}$ and weighed with soil (COGO, 1978). The dry soil weight to watersediment mixture weight expressed the sediment concentration $\left(\mathrm{kg} \mathrm{L}^{-1}\right)$. The soil disaggregation rate (D) was determined according to Eq. 1:

$$
\mathrm{D}=\frac{\mathrm{Mss}}{\mathrm{A} \mathrm{Dc}}
$$

wherein $D$ is the soil disaggregation rate $\left(\mathrm{Kg} \mathrm{m}^{-2} \mathrm{~s}^{-1}\right)$, Mss is the dry disaggregated soil weight $(\mathrm{Kg}), A$ is the plot area $\left(\mathrm{m}^{2}\right)$, and $D c$ is the collection duration.

The soil losses were expressed by the Eq. 2:

$$
\mathrm{Ps}=\frac{\sum(\mathrm{Q} C s \mathrm{t})}{\mathrm{A}}
$$

wherein $P S$ is the soil losses $\left(\mathrm{Kg} \mathrm{m}^{-2}\right), Q$ is the water flow $\left(\mathrm{L} \mathrm{s}^{-1}\right), C s$ is the sediment concentration $\left(\mathrm{Kg} \mathrm{L}^{-1}\right), T$ is the collection intervals (300 s), and $A$ is the plot area $\left(\mathrm{m}^{2}\right)$.

The infiltration rate was then obtained by considering the precipitation intensity and the resulting runoff rate (BRANDÃO; PRUSKI; SILVA, 2006).

The total soil organic carbon (TC) content at depth of $0-20 \mathrm{~cm}$ was determined before and after the crop cycle. The analysis was performed according to recommendations of Embrapa (1997) on wet basis.

Six plants from each plot were selected to evaluate soil temperature below the mulch, which was measured daily using a digital thermometer.

The data were subjected to analysis of variance (ANOVA) and the Tukey's test at 5\% significance was used to compare the means of the treatments, using the SAEG software.

\section{RESULTS AND DISCUSSION}

The sorghum with mulch had the highest moisture content before the simulated rainfall, differing from the sorghum without mulch (Figure 1). The interval between the first and the second rainfall was 32 days, and between the second and third rainfall was 56 days. This denotes the efficiency of mulching in maintaining soil moisture at suitable levels for crop development.

The soil moisture before the third rainfall were lower than before the previous ones (Figure 1). This result is explained by the time of the third evaluation period, which was in December, month of low rainfall in the region of Cruz das Almas. Similar results were found by Santos et al. (2008) in a fluvic Neosol in the Riacho Mimoso Basin, Pesqueira PE, Brazil, with effects of soil coverage and conservationist treatments on the water infiltration rate. According to these authors, treatments arranged in slopes and with mulch have less soil disaggregation and loss, and the soil have a greater water retention. Costa, Melo and Ferreira (2007) evaluated the efficiency of mulching in maintaining soil moisture by using dry leaves on the soil in a greenhouse and found that the soil covered with dry acacia leaves presented higher moisture compared to the unprotected soil.

Precipitation is one of the main factors affecting soil moisture, which is an important factor for the development of plants, since the moisture content controls soil temperature, aeration, and mechanical resistance to penetration; thus, in soils with high moisture, plants respond well to cultivation practices (TORRES et al., 2006). 


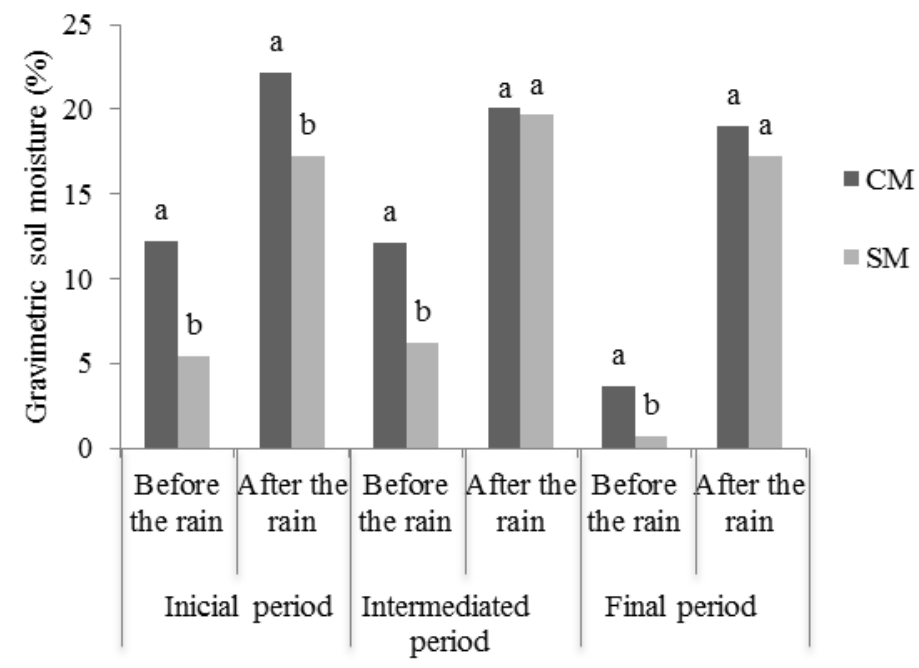

Figure 1. Gravimetric soil moisture during the cycle of sorghum crops subjected to simulated rainfall in three different periods, and treatments with (CM) and without (SM) mulching. Bars followed by the same letters in each simulated rain period were similar by the Tukey's test at $5 \%$ probability.

The soil in the treatment with mulch maintained better its moisture after the rainfall than the treatment without mulch, with a significant difference between treatments in the first evaluation period (Figure 1).

The treatment with mulch had the highest carbon and organic matter content, differing significantly from the treatment without mulch (Table 2). The use of organic material as soil coverage contributes to carbon content in the surface layer. According to Leite et al. (2010), the use of plant residues improves soil chemical attributes and increases total organic and microbial carbon stock of the soil up to $20 \mathrm{~cm}$ deep.

Table 2. Organic carbon and soil organic matter content in the evaluated treatments.

\begin{tabular}{cccc}
\hline Treatment & Layer $(\mathrm{cm})$ & $\begin{array}{c}\mathrm{SOC} \\
\left(\mathrm{g} \mathrm{kg}^{-1}\right)\end{array}$ & $\begin{array}{c}\mathrm{SOM} \\
\left(\mathrm{g} \mathrm{kg}^{-1}\right)\end{array}$ \\
\hline $\mathrm{CM}$ & $0-20$ & $10.11 \mathrm{a}$ & $17.43 \mathrm{a}$ \\
$\mathrm{SM}$ & $0-20$ & $8.00 \mathrm{~b}$ & $13.79 \mathrm{~b}$ \\
\hline
\end{tabular}

CM (sorghum crop with mulch), SM (sorghum crop without mulch); SOC: soil organic carbon. SOM: soil organic matter. Means followed by the same letter in the columns do not differ by the Tukey's test at $5 \%$ probability.

Several soil management techniques can provide similar effects. No-tillage, for example, is a management system in which crop residues are maintained on the soil, protecting the soil from erosion, and contributing to organic carbon and organic matter contents in the soil. However, Campos et al. (2013) emphasize that this contribution is more pronounced after five years of implantation, due to the stability of humic fractions and lower degree of mineralization of the soil organic matter. Thus, a long time of maintenance of crop residues in the soil is necessary to reach considerable increases in soil organic carbon. However, although the sorghum crop presented a cycle of only four months, it was possible to observe increments in organic carbon content in the soil (Table 2).

The water infiltration rates in the soil were higher at 54 and 110 days after planting (Figure 2B), and the surface runoff was lower in these evaluations (Figure 2A) because the plant mass increases as the crop develop, providing greater protection to the soil surface and favoring the infiltration rate. The infiltration curves showed higher infiltration at the beginning of the test, which is explained by the lower soil moisture. The mean infiltration rate was $41.37,57.64$ and $54.37 \mathrm{~mm} \mathrm{~h}^{-1}$ in the measurements at 12,54 and 110 days after planting, respectively. The surface runoff measured at 12 DAP presented the highest rates. 

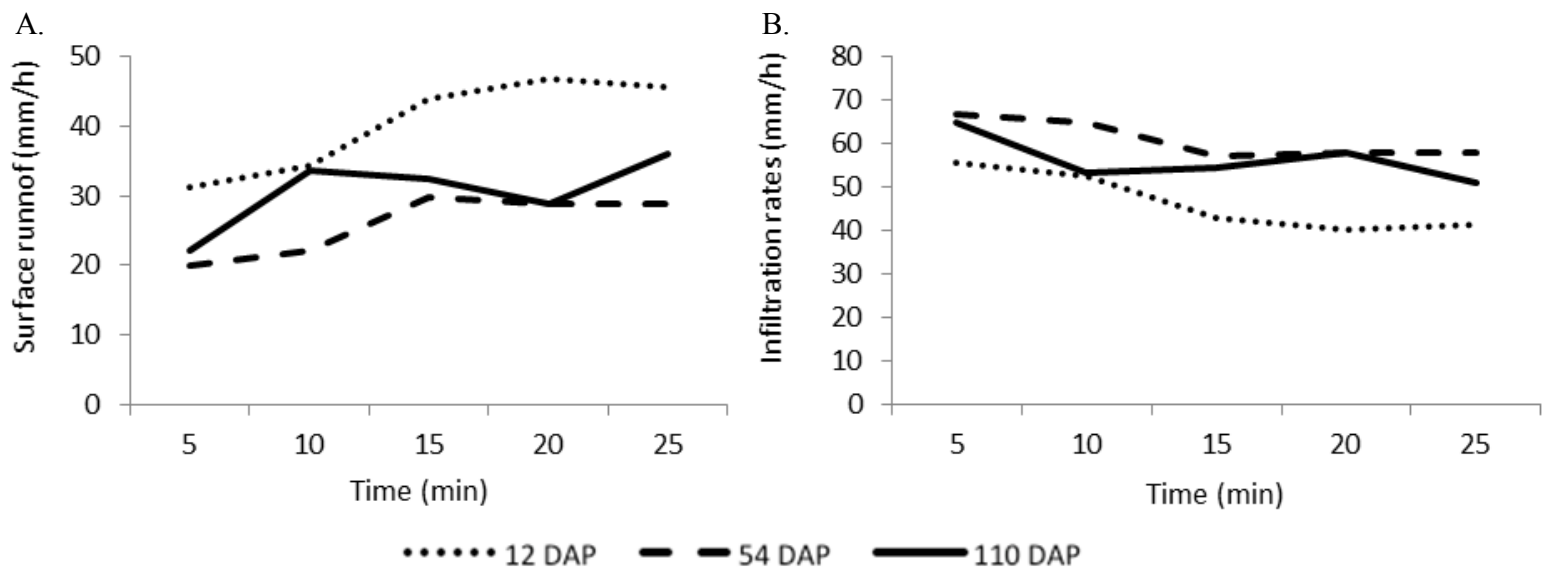

Figure 2. Infiltration rates (B) and surface runoff (A) in sorghum crops with mulch, measured at 12, 54 and 110 days after planting (DAP).

Surface runoff occurred only in the treatment without mulch. The treatment with mulch provided a physical barrier to runoff; this resulted in reduced water speed, and allowed the precipitated water to infiltrate into the soil, thus avoiding surface runoff in all periods evaluated in this treatment. This result confirms those found by Ramos et al. (2011), who highlighted the importance of soil coverage in water and soil conservation. This was also found by
Bagatini et al. (2011), who found lower total water losses in sorghum with organic fertilization in the initial phase of the crop.

Figure 3 shows the soil loss evaluated at 12 , 54 and 110 DAP in the treatment without mulch. The absence of mulch resulted in a high soil loss from the beginning of the measurements, and did not differ significantly from the later measurements.

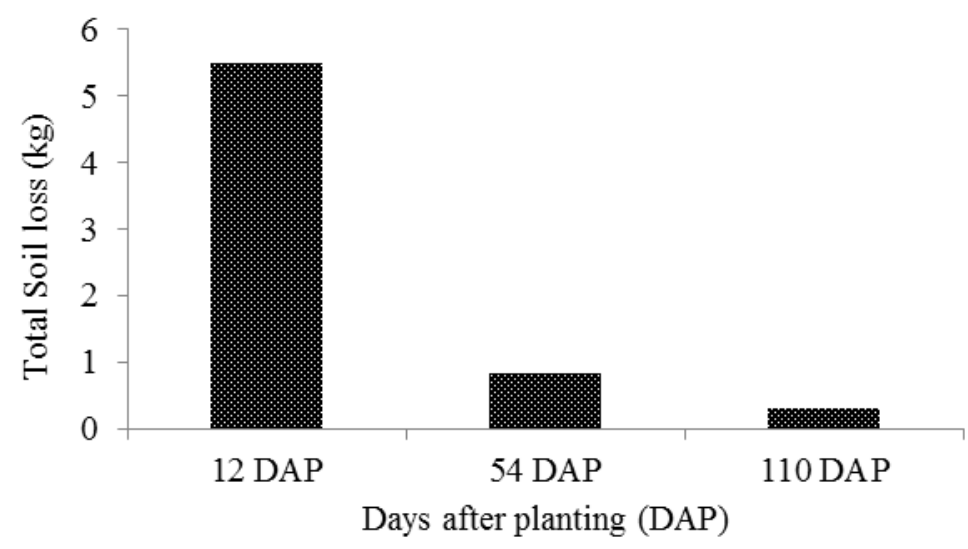

Figure 3. Total soil loss $(\mathrm{kg})$ in sorghum crops without mulch, evaluated at 12, 54 and 110 days after planting (DAP).

This result showed the importance of soil coverage for the maintenance of the soil, since the treatment without mulch presented a total soil loss of $6.63 \mathrm{Kg}\left(22.1 \mathrm{Mg} \mathrm{ha}^{-1}\right)$ with a 30-minute precipitation, and the treatment with mulch showed no loss with the same precipitation. Gobbi et al. (2011) found similar results, with the treatment without soil coverage presenting significantly higher soil losses than those with some soil coverage.

The results obtained for soil loss can be complemented by the soil disaggregation rates (Table 3), which presented similar trend, with no significant differences between the means over time. The high disaggregation rates occurred at the beginning of the crop development were due to its low phytomass production, which was not enough to reduce the impact of raindrops on the soil surface, resulting in fragmentation and dragging of soil particles; these rates remained high throughout the crop cycle. Ferreira et al. (2010) evaluated the effect of different soil coverage on the erosion process with simulated rainfall and found that the total soil loss in treatments with uncovered soil was, on average, four times that of soils covered with straw. 
T. E. M. S. SOUZA et al.

Table 3. Soil disaggregation rates in sorghum crops without mulch, evaluated at 12,54 and 110 days after planting (DAP).

\begin{tabular}{cc}
\hline DAP & Disaggregation rate $\left(\mathrm{Kg} \mathrm{m}^{-2} \mathrm{~s}^{-1}\right)$ \\
\hline 12 & $31.26 \times 10^{-3} \mathrm{a}$ \\
54 & $2.19 \times 10^{-3} \mathrm{a}$ \\
110 & $2.15 \times 10^{-3} \mathrm{a}$ \\
\hline
\end{tabular}

The soil temperature, evaluated at 30,60 and 90 days, showed significantly lower means for the treatment with mulch compared to the treatment without mulch in all periods (Figure 4). The material used as mulch in the sorghum crop was efficient in maintaining soil temperature. This can be attributed to the effect of the vegetation coverage in preventing the heating of the soil to the temperatures of the uncovered soil. This management reduces the evapotranspiration rate and favors the maintenance of water accumulation in the soil (SANTOS et al., 2011).

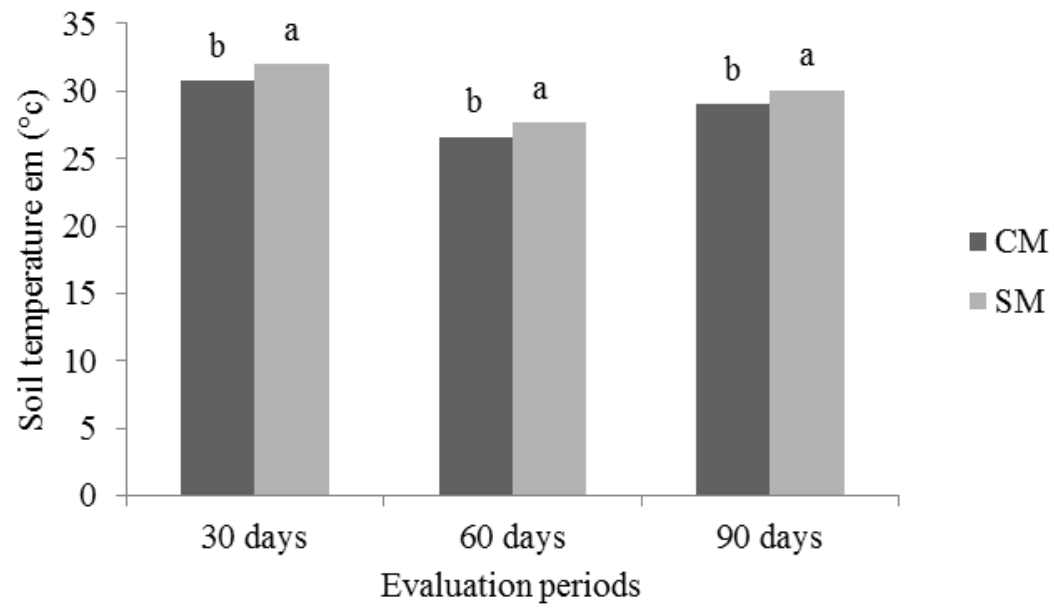

Figure 4. Soil temperature during the cycle of sorghum crops with (CM) and without (SM) mulch using different soil managements in three evaluation periods after planting.

According to Resende et al. (2005), the use of soil coverage maintains the temperature gradient approximately $3.5^{\circ} \mathrm{C}$ lower than the use of uncovered soils. High soil temperature may be a limiting factor for crop development. This is denoted by the lower soil temperature found in the evaluation at 60 DAP (Figure 4).

\section{CONCLUSIONS}

The use of mulch in sorghum (Sorghum bicolor L. Moench) crops is efficient for soil water retention and longer maintenance of soil moisture between rainfall intervals than the use of uncovered soil.

The use of mulch in sorghum crops assists in the maintenance of lower soil temperatures.

The applied mulch is efficient in increasing the soil organic carbon content during the four months of the sorghum cycle.

The use of mulch reduces soil erosion rates, favors the water infiltration into the soil, and prevents runoff.

Sorghum crops show better soil coverage index from 54 days after planting.

\section{ACKNOWLEDGMENTS}

The authors thank the CNPq (Brazilian National Council for Scientific and Technological Development) for the financial support to carry out this research, and the UFRB (Federal University of the Recôncavo da Bahia) for the concession of the area and support in conducting this experiment.

\section{REFERENCES}

ALVINO, F. C. G. et al. Rendimento de fitomassa do sorgo sacarino sob sistemas de captação de água "in situ”. Agropecuária Científica no Semiárido, Campina Grande, v. 8, n. 1, p. 54-59, 2012.

BAGATINI, T. et al. Perdas de solo e água por erosão hídrica após Mudança no tipo de uso da terra, em dois métodos de preparo do solo e dois tipos de adubação. Revista Brasileira Ciência do Solo, Viçosa, v. 35, n. 1, p. 999-1011, 2011.

BRANDÃO, V. S.; PRUSKI, F. F.; SILVA, D. D. Infiltração da água no solo. 3 . ed. Viçosa, MG: UFV, 2006. 120 p. 
CAMPOS, L. P. et al. Estoques e frações de carbono orgânico em Latossolo Amarelo submetido a diferentes sistemas de manejo. Pesquisa Agropecuária Brasileira, Brasília, v. 48, n. 2, p. 304-312, 2013.

CARDOSO, D. P. et al. Atributos fitotécnicos de plantas de cobertura para a proteção do solo. Revista verde de agroecologia e desenvolvimento sustentável, Mossoró, v. 8, n. 1, p. 375-382, 2013.

COGO, N. P. Uma contribuição à metodologia de estudo das perdas de erosão em condições de chuva natural: Sugestões gerais, medição dos volumes, amostragem e quantificação de solo e água da enxurrada, $1^{\text {a }}$ aproximação. In: ENCONTRO NACIONAL DE PESQUISA SOBRE CONSERVAÇÃO DO SOLO, 2., 1978, Passo Fundo. Anais... Passo Fundo: EBPA, 1978. p. 75-98.

COSTA, D. M. A.; MELO, H. N. S.; FERREIRA, S. B. Eficiência da cobertura morta na retenção de umidade no solo. Holos, Natal, v. 23, n. 2, p. 60-69, 2007.

EMPRESA BRASILEIRA DE PESQUISA AGROPECUÁRIA - EMBRAPA. Manual de métodos de análise do solo. 2. ed. Rio de Janeiro, RJ: CNPS, Ministério da Agricultura e do Abastecimento, 1997, 212 p.

EMPRESA BRASILEIRA DE PESQUISA AGROPECUÁRIA - EMBRAPA. Sistema brasileiro de classificação de solos. 2. ed. Brasília, DF: Embrapa, 2006. 353 p.

FERREIRA, A. O. et al. Influência da declividade e de níveis de cobertura do solo no Processo de erosão com simulada. Revista verde de agroecologia e desenvolvimento sustentável, Mossoró, v. 5, n. 1, p. 182-190. 2010.

GOBBI, E. et al. Erosão hídrica associada a algumas variáveis Hidrológicas em pomar de maçã submetido a diferentes manejos do solo. Revista Brasileira Ciência do Solo, Viçosa, v. 35, n. 2, p. 1013-1024, 2011.

LEITE, L. F. C. et al. Atributos químicos e estoques de carbono em Latossolo sob plantio direto no cerrado do Piauí. Revista Brasileira de Engenharia Agrícola e Ambiental, Campina Grande, v. 14, n. 1, p. $1273-1280,2010$.

LIMA, C. A. Perdas de solo, água e nutrientes em cultivo de mandioca no Recôncavo da Bahia. 2013. 80 f. Dissertação (Mestrado em Engenharia Agrícola: Área de manejo de água e solo) -
Universidade federal Rural de Pernambuco, Recife, 2013.

PEREIRA, R. C.; ALBANEZ, J. M.; MAMÉDIO, I. M. P. Diversidade da meso e macrofauna edáfica em diferentes sistemas de manejo de uso do solo em Cruz das Almas - BA. Magistra, Cruz das Almas, v. 24, n. 2, p. 63-76, 2012.

RAMOS, F. T. et al. Erosão por salpicamento sob diferentes sistemas de manejo em um Neossolo Quartzarênico em Cáceres (MT). Global Science and Technology, Rio Verde, v. 4, n. 1, p. 38-50, 2011.

RESENDE, F. V. et al. Uso de cobertura morta vegetal no controle da umidade e temperatura do solo, na incidência de plantas invasoras e na produção da cenoura em cultivo de verão. Ciência Agrotécnica, Lavras, v. 29, n. 2, p. 100-105, 2005.

SANTOS, A. P. et al. Efeito da cobertura do solo sobre os teores de macronutrientes na parte aérea do meloeiro fertirrigado. Revista verde de agroecologia e desenvolvimento sustentável, Mossoró, v. 6, n. 1, p. 231-234, 2011.

SANTOS, T. E. M.; MONTENEGRO, A. A. A.; SILVA JUNIOR, V. P. Erosão hídrica e perda de carbono orgânico em diferentes tipos de cobertura do solo no semiárido, em condições de chuva simulada. Revista Brasileira de Recursos Hídricos, Porto Alegre, v. 13, n. 2, p. 113-125, 2008.

SOUZA, E. R. et al. Temporal stability of soil moisture in irrigated carrot crops in Northeast Brazil. Agricultural Water Management, Amsterdam, v. 99, n. 3, p. 26-32, 2011.

TORRES, J. L. R. et al. Influência de plantas de cobertura na temperatura e umidade do solo na rotação milho-soja em plantio direto. Revista Brasileira Agrociência, Pelotas, v. 12, n. 2, p. 107113, 2006. 